\title{
EFFECT OF CERTAIN ANTI-ARTHRITIC COMPOUNDS ON THE PERMEABILITY OF SYNOVIAL MEMBRANE IN THE RABBIT
}

\author{
BY \\ G. W. G. SHARP \\ Institute of Clinical Research, Middlesex Hospital Medical School, London
}

Little is known of the pathogenesis of rheumatoid arthritis. The disease has many characteristics of infection, but no causative agent has been discovered. The situation is confused and hypersensitivity, auto-immunity, metabolic abnormality, and endocrine imbalance have all been suggested as possible causes, with or without a precipitating infectious or stress phase. One approach to the elucidation of this problem, which has only been possible in recent years, is to seek for common mechanisms of action in drugs exerting a beneficial effect on the course of the disease. The essential changes produced by these compounds must be, at least in part, the reverse of those brought about by the disease. Assessment of beneficial effect is difficult in rheumatoid arthritis, but many workers believe that cortisone, cortisol, and similar synthetic steroids, gold, salicylates, chloroquine, and phenylbutazone all exert some favourable effect, while reports from Italy suggest that chlorpromazine may also be useful. These are markedly different chemically and therefore suited for this type of comparative pharmacological study.

The effect of these compounds on the permeability of synovial membrane was studied for several reasons. For instance, the first detectable change in an inflammatory state is an increase in permeability followed by exudation of fluid, oedema,

* Present address: Massachusetts General Hospital, Boston, 14, Massachusetts, U.S.A. and tissue disorganization. Synovial membrane is clearly involved in the inflammatory process of rheumatoid arthritis, and cortisol, which is undoubtedly beneficial, even if only temporarily, has been shown to decrease membrane permeability (Sharp, 1962).

\section{Methods}

The method used for assessing permeability changes was essentially that of Seifter and Baeder (1954).

Healthy male rabbits weighing not less than $3 \mathrm{~kg}$. were used in groups of six for each compound under test and for the two control groups. Rabbits in each group received either the compound under test or normal saline solution, according to the schedules given belows after which the permeability of the synovial membrane: was assessed. The dosage used was approximately doutle that of normal therapy on a dose $/ \mathrm{kg}$. body weight basis. Though the quantities administered in practice differ widely, the author assumed that the values shown in Table I were reasonable estimates and the rabbit doses were calculated accordingly.

The high dose levels were used deliberately to demonstrate an effect which may be more marked in diseased than healthy membranes and because two of the compounds (sodium aurothiomalate and chloroquine phosphate) are known to have a delayed onset of therapeutic action.

Group 1.-2 ml. 0.9 per cent. sodium chloride solution administered by intraperitoneal (i.p.) injection daily for 14 days.

TABIE I

CALCULATION OF DOSAGE

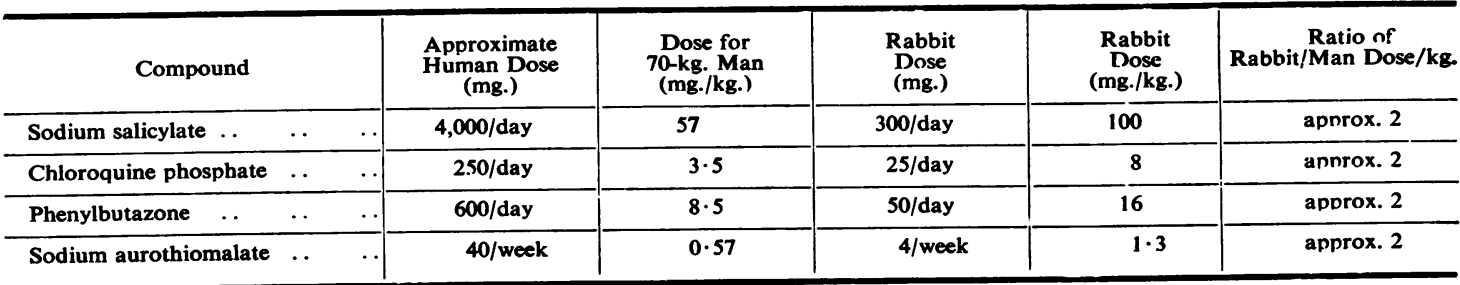


Group 2.-25 mg. chlorpromazine hydrochloride in $5 \mathrm{ml}$. solution administered by i.p. injection daily for 7 days.

Group 3. $-25 \mathrm{mg}$. chloroquine phosphate in $2 \mathrm{ml}$. solution administered by i.p. injection daily for 14 days.

Group 4.-50 mg. phenylbutazone in $2 \mathrm{ml}$. solution administered by i.p. injection daily for 7 days.

Group 5.-300 mg. sodium salicylate in $2 \mathrm{ml}$. solution administered by i.p. injection daily for 7 days.

In Groups 1 to 5 the rabbits were tested 30 to 35 minutes after injection on the last day of treatment.

Group 6.-0.1 ml. 0.9 per cent. sodium chloride solution administered by intramuscular (i.m.) injection in the left hind leg once each week for 6 weeks.

Group 7. $-2 \mathrm{mg}$. sodium aurothiomalate in $0.1 \mathrm{ml}$ administered by i.m. injection once each week for 4 weeks, then $4 \mathrm{mg}$. in $0.1 \mathrm{ml}$. for 2 weeks.

In Groups 6 and 7 the rabbits were tested 2 days after the last injection. Group 1 was the control for Groups 2 to 5 and Group 6 for Group 7.

The synovial membrane permeability was assessed as follows: The rabbits were anaesthetized by intravenous injection of pentobarbitone sodium at a dose level of $50 \mathrm{mg} . / \mathrm{kg}$. and maintained lightly anaesthetized by small additional doses at approximately 30-minute intervals. Rabbits in Group 2 were anaesthetized cautiously with smaller doses of pentobarbitone sodium because of the potentiating effect of chlorpromazine. The rabbits were placed on their backs and a soft rubber retention catheter lubricated with jelly inserted into the bladder via the urethra. The bladder was emptied and washed out with physiological saline solution. The inner aspect of the right hind leg was shaved at the talo-crural articulation and a 26-gauge 1-in. needle inserted into the joint cavity. Access was gained through the opening formed by the lateral and medial malleoli of the tibia-fibula and the tarsus of talus. $2,100 \mu \mathrm{g}$. phenolsulphonphthalein in $0.15 \mathrm{ml}$. 0.85 per cent. saline solution was injected. After extending and flexing the joint slowly, the leg was maintained in the extended position by means of a cord tied distal to the joint and a supporting splint. Urine samples were obtained by washing the bladder with saline solution warmed to $37^{\circ} \mathrm{C}$. All experiments were carried out in a room with an air temperature of $20-21^{\circ} \mathrm{C}$. The permeability of the synovial membrane surrounding the joint was assessed in terms of the urinary dye excretion rate. Urine was collected 15 minutes after the injection of dye and thereon at 20-minute intervals. Phenolsulphonphthalein in urine was estimated by colorimetric comparison with standard solutions of the dye after full colour development with sodium hydroxide solution and dilution. A photo-electric colorimeter and filter at $520 \mathrm{~m} \mu$ was used.

\section{Results}

The results are presented in Table II, where the amounts of phenolsulphonphthalein excreted in the first 15 minutes after injection and each 20-minute period thereafter are expressed as the mean \pm standard error for each group of rabbits. Student's " $t$ " test was applied to assess the significance of the results, and probability values are presented only where results significantly different from the control results were obtained. It should be noted that the test for significance has been applied to the difference between the amount of dye in any particular urine sample and that in the corresponding sample of the control group. The test of significance applied here is more cautious than a test applied to cumulative excretion, but it allows the onset, duration, and intensity of permeability effects to be seen clearly.

TABLE II

PHENOLSULPHONPHTHALEIN EXCRFTION IN URINE

Dye excreted during first 15 minutes after injection and each 20 -minute period thereafter, expressed in $\mu \mathrm{g}$. \pm S.E. for control and drug-treated animals

\begin{tabular}{|c|c|c|c|c|c|c|c|c|}
\hline \multirow{3}{*}{$\begin{array}{c}\text { Group } \\
1\end{array}$} & \multirow{2}{*}{\multicolumn{3}{|c|}{ Drug }} & \multicolumn{5}{|c|}{ Minutes after Injection } \\
\hline & & & & 15 & 35 & 55 & 75 & 95 \\
\hline & Saline (i.p.) . . & .. & $\cdots$ & $129 \cdot 8 \pm 24 \cdot 4$ & $620 \cdot 0 \pm 26 \cdot 1$ & $444 \cdot 0 \pm 16 \cdot 6$ & $319 \cdot 2 \pm 20 \cdot 6$ & $211 \cdot 4 \pm 28 \cdot 3$ \\
\hline 2 & Chlorpromazine & $\cdots$ & $\cdots$ & $\begin{array}{c}25 \cdot 2 \pm 11 \cdot 1 \\
p<0.01\end{array}$ & $\begin{array}{c}225 \cdot 8 \pm 56 \cdot 0 \\
p<0 \cdot 001\end{array}$ & $\begin{array}{c}311 \cdot 6 \pm 41 \cdot 1 \\
p<0.05\end{array}$ & $264 \cdot 0 \pm 18 \cdot 1$ & $231 \cdot 8 \pm 17 \cdot 6$ \\
\hline 3 & Chloroquine & $\cdots$ & $\cdots$ & $\begin{array}{c}50.4 \\
p<0.05\end{array}$ & $\begin{array}{c}364 \cdot 0 \pm 65 \cdot 6 \\
p<0 \cdot 01\end{array}$ & $519 \cdot 0 \pm 36 \cdot 2$ & $388.8 \pm 33.6$ & $258 \cdot 8 \pm 25 \cdot 1$ \\
\hline 4 & Phenylbutazone & $\cdots$ & $\cdots$ & $\begin{array}{l}4.6 \pm 1.7 \\
p<0.001\end{array}$ & $\begin{array}{c}199 \cdot 6 \pm 15 \cdot 4 \\
p<0.001\end{array}$ & $436 \cdot 4 \pm 27 \cdot 6$ & $\begin{array}{c}397.6 \pm 15.0 \\
p<0.05\end{array}$ & $262 \cdot 8 \pm 9 \cdot 7$ \\
\hline 5 & Sodium salicylate & $\cdots$ & $\cdots$ & ${ }_{p}^{16 \cdot 2}<0.01^{8 \cdot 2}$ & $\begin{array}{c}173 \cdot 0 \pm 0.38 \cdot 4 \\
p<0.001\end{array}$ & $336 \cdot 8 \pm 55 \cdot 5$ & $285 \cdot 6 \pm 32 \cdot 0$ & $186 \cdot 0 \pm 14 \cdot 2$ \\
\hline 6 & Saline (i.m.) .. & $\cdots$ & $\cdots$ & $168 \cdot 2 \pm 18 \cdot 6$ & $62.3 \cdot 0 \pm 44 \cdot 5$ & $387 \cdot 6 \pm 17 \cdot 6$ & $256 \cdot 8 \pm 12 \cdot 3$ & $191 \cdot 0 \pm 11 \cdot 6$ \\
\hline 7 & Sodium aurothiom & alate & . & $\begin{array}{c}99.6 \pm 12.6 \\
p<0.05\end{array}$ & $\begin{array}{c}353 \cdot 2 \pm 41 \cdot 2 \\
p<0 \cdot 01\end{array}$ & $465 \cdot 0 \pm 39 \cdot 9$ & $\begin{array}{c}400.0 \pm 30.3 \\
p<0.01\end{array}$ & $228.6 \pm 23.9$ \\
\hline
\end{tabular}


Control Results.--In both control groups (1 and 6) the pattern of phenolsulphonphthalein excretion was similar. Excretion started less than 15 minutes after injection and reached peak levels within 35 minutes. Under the conditions of these experiments the "peak" was clear cut with a rapid rise from 15 to 35 minutes and a marked fall from 35 to 55 minutes (Figs 1 and 2). Decreased permeability of synovial membrane is shown by decreased dye excretion and delayed peaks relative to the control results.

Test Results.-Treatment with all five compounds resulted in decreased dye excretion over the period of the experiments and delayed peak excretion times. The changes were similar to those caused by the intra-articular injection of anti-inflammatory steroids in the rabbit (Sharp, 1962), though less intense. Under these particular conditions the greatest decrease in permeability occurred when sodium salicylate and chlorpromazine were tested, these being more effective than phenylbutazone, gold, or chloroquine (Figs 1 and 2). Phenylbutazone was as effective in depressing permeability as salicylate during the first hour after administration but was less effective thereafter. During the second hour its effectiveness was similar to that of gold and chloroquine, the two compounds producing the least marked depression of permeability. In comparing the action of these compounds the different dosage schedules must be kept in mind. The importance of these results dwells in the fact that all five of the anti-arthritic compounds decreased membrane permeability.

\section{Discussion}

The results of this study show that chlorpromazine, chloroquine, phenylbutazone, sodium salicylate, and sodium aurothiomalate all decrease the permeability of synovial membrane. We have to assess, therefore, the relevance of permeability decreasing activity to therapeutic effectiveness, the importance of permeability changes in the disease process, and the

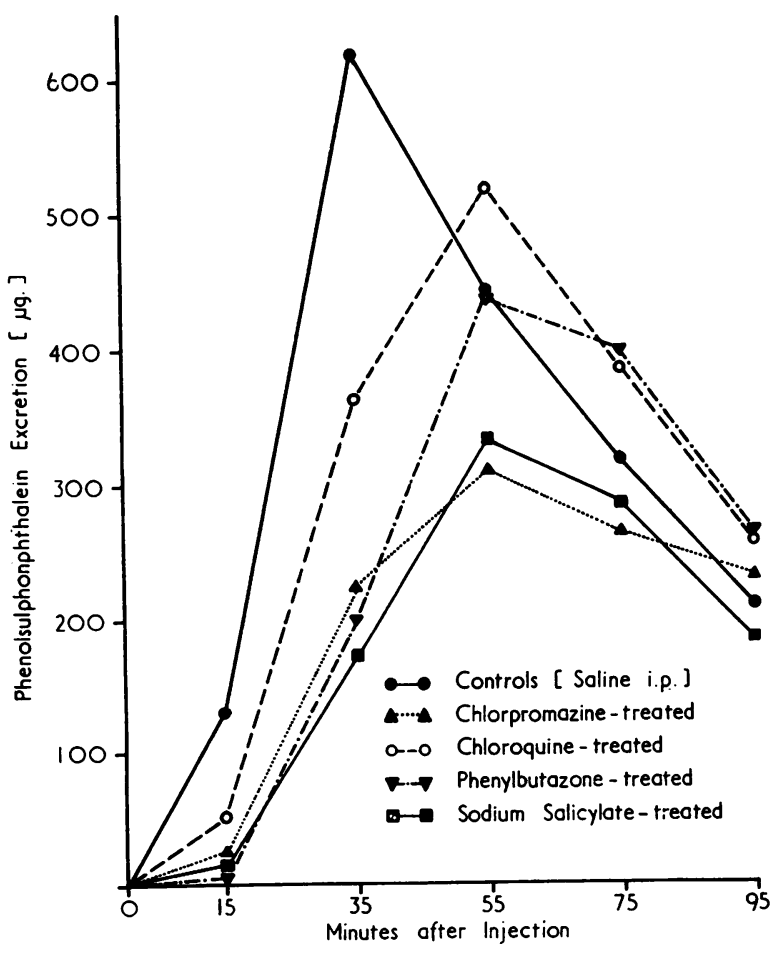

Fig. 1.-Phenolsulphonphthalein excretion, expressed in $\mu \mathrm{g}$. during the first 15 minutes after injection of dye and each 20-minute period thenceforward.

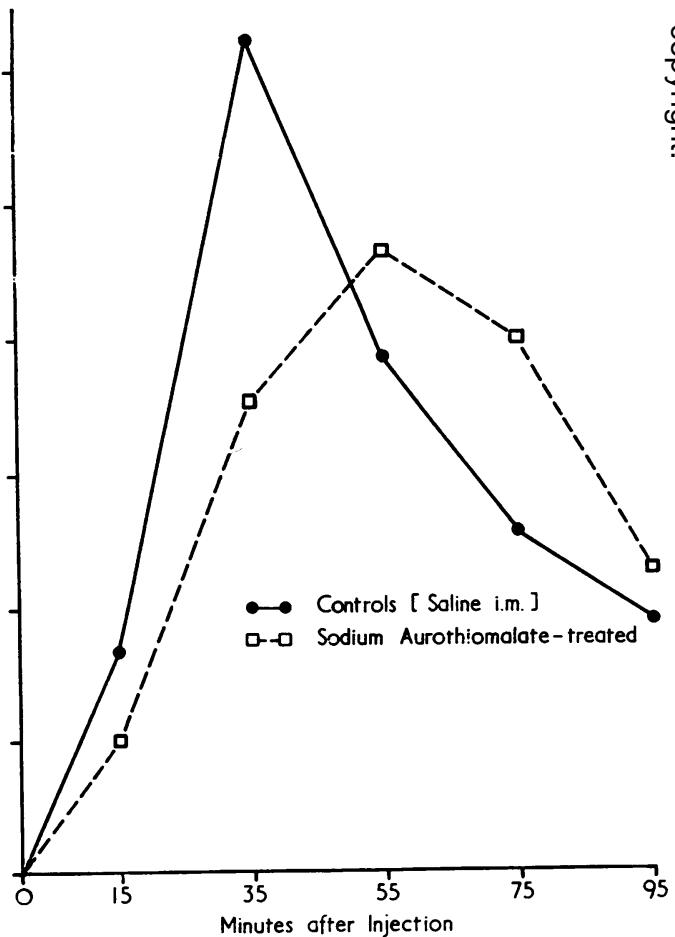

Fig. 2.-Phenolsulphonphthalein excretion, expressed in $\mu \mathrm{g}$. during the first 15 minutes after injection of dye and each 20-minute period thenceforward. 
value of this test of synovial permeability as a screening test for anti-arthritic compounds. The therapeutic effectiveness of these compounds has been demonstrated and numerous papers published. Among them, reports on the effectiveness of gold (Empire Rheumatism Council, 1961), phenylbutazone (Meanock and Lewis-Faning, 1961), chloroquine (Popert, Meijers, Sharp, and Bier, 1961), steroids (Ward, Polley, Power, Mason, Slocumb, and Hench, 1958), and salicylates compared with steroids (Empire Rheumatism Council, 1957) on the course of rheumatoid arthritis. Recent work in Italy suggested that chlorpromazine might also be effective (Galli, Caviglia, Solari, and Pavero, 1958) and the drug was included here because of this report. Experimental studies have shown that salicylates and phenylbutazone depress the absorption of dye from the joint and the site of action was defined on the synovial membrane (Bianchi, 1953, 1954). Anti-inflammatory steroids exert a similar effect (Sharp, 1962), and it seems likely, from the results presented here and the time relationships of the dye excretion, that gold, chloroquine, and chlorpromazire are also active at this site by direct or indirect means. The relationship between these observations and the arthritic process is uncertain. The facts that all these anti-arthritic compounds decrease permeability and that inflammation is associated with an increase suggests a direct association. The high intensity of action of salicylates and phenylbutazone relative to gold and chloroquine also suggests a parallel. For instance, the results of clinical studies show that gold and chloroquine treatment must be prolonged before it becomes effective, that other forms of treatment have more acute effects, and that treatment is essentially palliative rather than curative. That chloroquine and gold produced less effect in these experiments than salicylates or phenylbutazone may reflect the slow onset of their beneficial effect provided that this is linked with the ability to decrease synovial permeability. More direct evidence of an association between the disease process and permeability change has been obtained from patients in whom the clearance of injected radio-sodium was higher in severely-affected rheumatoid arthritic joints than in joints with mild involvement (Harris, Millard, and Banerjee, 1958). Where clinical improvement of the joint occurred a sharp decrease in clearance was found, and in one of these patients where deterioration occurred at a later date the clearance had increased again. Intra-articular cortisol produced a fall in clearance. These results are similar to those of other workers using radioactive iodinelabelled albumin to study the difference between clinically normal and affected knee joints (Ahlström, Gedda, and Hedberg, 1956). Diseased knees had a higher clearance rate than normal knees, while intra-articular cortisol reduced the rate. This is clear evidence of an association between the disease and increased permeability and between cortisol and decreased permeability.

The ability to decrease synovial membrane permeability may be a valid preliminary screening test for anti-arthritic compounds. This was first suggested by Seifter, Baeder, Begany, Rosenkranz, Djzrassi, Pataki, and Kaufmann (1950) and was cautiously assessed by Bianchi (1953), who pointed out that the test does not necessarily assess synovial membrane permeability because changes in the periarticular tissue, capillaries, or kidneys may affect the results. These must be eliminated in a strictly accurate screening test. It was shown also that benzoylcarbinolacetate decreased membrane permeability, but that its therapeutic value was uncertain. Other workers could not agree that the test was suitable for screening purposes (Paul, Hodges, Knouse, and Wright, 1952; Hidalgo, McClure, Henderson, Whitehead, and Smyth, 1952), though Seifter and Baeder (1954) believed that the disagreement was largely due to differences in technique. It is clear that the method may be considered inadequate if compounds are found which decrease permeability but are ineffective in therapy though the relationship between the disease and permeability change may still be valid. That is, the lack of therapeutic activity may be due to factors of absorption, penetration, or metabolism. The method certainly becomes invalid if compounds are found which are effective therapeutically but do not decrease the permeability of synovial membrane, though all the therapeutically active compounds tested here have this activity. These effects on synovial permeability must not obscure the facts that rheumatoid arthritis is a systemic disease and that only partial relief is provided by treatment. For instance, prednisolone and chloroquine provide subjective and objective improvement, although radiological deterioration may occur simultaneously. Permeability changes also occur throughout the body and water and electrolyte shifts in different compartments provide evidence of this. Both sodium salicylate and chloroquine can increase plasma volume by as much as 20 per cent.

The fact that all five compounds tested decreased synovial membrane permeability underlines the need for more fundamental research into the nature of the permeability changes in disease and in drug-treated conditions. Mechanism of action could involve concentration or polymerization changes of hya- 
luronic acid, pore-size variations in the membrane, and change of ionic charge in conjunction with the latter. The need to study differential permeability changes (Sundblad, Jonsson, and Nettelbladt, 1961) is also important.

\section{Summary}

A study of the absorption of phenolsulphonphthalein from the talo-crural joint of the rabbit has been made during an investigation of the effect of certain anti-arthritic compounds on the permeability of synovial membrane. Chloroquine phosphate, chlorpromazine, phenylbutazone, sodium salicylate, and sodium aurothiomalate all decreased the permeability of synovial membrane under differing dosage regimes. The decrease in membrane permeability is therefore a common pharmacological property of these anti-arthritic compounds. The implications of these observations and their relationship to the arthritic process are discussed.

The author wishes to express his gratitude to the Empire Rheumatism Council for their support during the course of this work, to the Clinical Research Committee of the Middlesex Hospital for facilities provided at the Institute of Clinical Research, and to Dr. J. D. N. Nabarro for advice and encouragement. The author is also grateful to Dr. W. M. W. Inman of the Imperial Chemical. Industries Ltd. for a gift of chloroquine phosphate.

\section{REFERENCES}

Ahlström, S., Gedda, P. O., and Hedberg, H. (1956). Acta rheum. scand., $2,129$.

Bianchi, C. (1953). Brit. J. Pharmacol., 8, 130.

- (1954). Ibid., 9, 166.

Empire Rheumatism Council (1957). Ann. rheum. Dis., 16, 277.

- (1961). Ibid., 20, 315.

Galli, T., Caviglia, E., Solari, S., and Pavero, A. (1958). Reumatismo, 10, 253.

Harris, R., Millard, J. B., and Banerjee, S. K. (1958). Ann. rheum. Dis., 17, 189.

Hidalgo, J., McClure, C. D., Henderson, J. B., Whitehead, R. W., and Smyth, C. J. (1952). Proc. Soc. exp. Biol. (N.Y.), 80, 97.

Meanock, R. I., and Lewis-Faning, E. (1961). Ann. rheum. Dis., 20, 161.
Paul, W. D., Hodges, R. E., Knouse, R. W., and Wright, C. S. (1952). Proc. Soc. exp. Biol. (N. Y.), 79, 68.

Popert, A. J., Meijers, K. A. E., Sharp, J., and Bier, F. (1961). Ann. rheum. Dis., 20, 18.

Seifter, J., and Baeder, D. H. (1954). Proc. Soc. exp. Biol. (N.Y.), 87, 276.

,-- , Begany, A. J., Rosenkranz, G., Djerassi, C., Pataki, J., and Kaufmann, S. (1950). Fed. Proc., 9, 314.

Sharp, G. W. G. (1962). J. Endocr. In the press.

Sundblad, L., Jonsson, E., and Nettelbladt, E. (1961). Nature (Lond.), 192, 1192.

Ward, L. E., Polley, H. F., Power, M. H., Mason, H. L., Slocumb, C. H., and Hench, P. S. (1958). Ann. rheum. Dis., 17, 145.

Effet de certains composés anti-arthritiques sur la perméabilité de la membrane synoviale du lapin

\section{RÉSUMÉ}

Au cours des recherches sur l'effet de certains composés anti-arthritiques sur la perméabilité de la membrane synoviale on étudia l'absorption de la phénolsulfonphtaléine d'une articulation de la patte du lapin. Le phosphate de chloroquine, la chlorpromazine, la phénylbutazone, le salicylate de soude et l'aurothiomalate de soude diminuaient la perméabilité de la membrane synoviale à de différents régimes posologiques. La diminution de la perméabilité de la membrane est donc une propriété pharmacologique commune de tous cescomposés anti-arthritiques. On discute les implications de ces observations et leur rapport au processus arthritique.

Efecto de ciertos compuestos antiartríticos sobre la permeabilidad de la membrana sinovial del conejo

\section{SUMARIO}

Durante una investigación sobre el efecto de ciertos compuestos antiartríticos sobre la permeabilidad de la membrana sinovial, se estudió la absorpción de la fenolsulfonftaleina de una articulación de la pierna del conejo. Fosfato de cloroquina, clorpromazina, fenilbutazona, salicilato de sosa y aurotiomalado de sosa-todos estos compuestos disminuían la permeabilidad de la membrana sinovial em diferentes regímenes posológicos. La diminución de la permeabilidad de la membrana es, pues, una propiedad farmacológica común de todos estos compuestos antiartríticos. Se discuten las implicaciones de estas observaciones y sus relaciones con el proceso artrítico. 